\title{
EFEK PENURUNAN KADAR KOLESTEROL TOTAL EKSTRAK ETANOL BUAH OYONG
}

\author{
Monang P.S Marpaung ${ }^{1, *}$, Rolan Rusli ${ }^{1,2, \dagger}$, Victoria Yulita F $^{1}$ \\ ${ }^{1}$ Laboratorium Penelitian dan Pengembangan Kefarmasian "Farmaka Tropis", \\ Fakultas Farmasi, Universitas Mulawarman, Samarinda \\ *Email : monang_marpaung@yahoo.co.id \\ ${ }^{2}$ Kelompok Bidang Ilmu Kimia Farmasi, Fakultas Farmasi, \\ Universitas Mulawarman, Samarinda \\ 'Email:rolan@farmasi.unmul.ac.id
}

\begin{abstract}
Metabolic abnormalities in hyperlipidemic can be caused by total cholesterol metabolism disorder. Treatment for patients with hyperlipidemia one is to use the plant as a traditional medicine. Luffa acutangula (L.) Roxb. has been used traditionally as folks a medicine plant. The research amied to determine effect of ridged gourd fruit against total blood cholesterol levels strain wistar male rats were made hypercholesterolemic by providing high-fat animal feed $20 \mathrm{~g}$ daily and PTU (0.01\%). Fifteen rats were divided into 5 groups: negative control given $\mathrm{Na}-\mathrm{CMC}$ $0.5 \%$, the positive control group given the drug suspension of simvastatin 0,18mg / $200 \mathrm{~g} \mathrm{BB}$ and the tes preparation were given $90 \%$ ethanol extract orally once a day with three variations dosage, namely $30 \mathrm{mg} / 200 \mathrm{~g} \mathrm{BB}, 50 \mathrm{mg} / 200 \mathrm{~g} \mathrm{BB}$ and $70 \mathrm{mg}$ $1200 \mathrm{~g} B B$. Test were evaluated by the decreasing of total cholesterol level using GOD-PAP method. The results showed the test group were able to reduce total cholesterol.
\end{abstract}

Keywords: Luffa acutangula (L.) Roxb, total cholesterol, rat.

\begin{abstract}
ABSTRAK
Kelainan metabolisme pada hiperlipidemia salah satunya adalah kelainan metabolime kolesterol total. Pengobatan untuk penderita hiperlipidemia salah satunya adalah dengan memanfaatkan tanaman sebagai pengobatan tradisional, antara lain Luffa acutangula (L.) Roxb. Tujuan penelitian ini adalah untuk mengetahui pengaruh pemberian ekstrak buah oyong terhadap kadar kolesterol total darah tikus putih jantan galur wistar yang dibuat hiperkolesterolemia dengan cara memberikan pakan ternak tinggi lemak 20g perhari dan PTU (propiltiourasil) $(0,01 \%) .15$ tikus jantan dikelompokkan menjadi 5 kelompok yaitu kontrol negatif
\end{abstract}


yang diberikan Na-CMC 0,5\%, kelompok kontrol positif yang diberikan suspensi obat simvastatin $0,18 \mathrm{mg} / 200 \mathrm{~g}$ BB dan 3 kelompok uji yang diberikan ekstrak etanol $90 \%$ buah oyong peroral dengan tiga variasi dosis, yaitu $30 \mathrm{mg} / 200 \mathrm{~g} \mathrm{BB}$, $50 \mathrm{mg} / 200 \mathrm{~g}$ BB dan $70 \mathrm{mg} / 200 \mathrm{~g}$ BB. Kadar kolesterol total serum tikus diukur dengan metode GOD-PAP. Hasil penelitian menunjukkan bahwa kelompok uji mampu menurunkan kadar kolesterol total.

Kata Kunci: Luffa acutangula (L.) Roxb, kolesterol total, tikus.

\title{
PENDAHULUAN
}

Penyakit aterosklerosis koroner mendorong penemuan berbagai bahan aktif yang dapat mencegah atau mengobati penyakit tersebut. Penanganan aterosklerosis yang biasa dilakukan adalah menurunkan kadar lemak atau kolesterol pada penderita dengan pemberian obat-obat hipolipidemik, antara lain golongan fibrat, senyawa-senyawa asam nikotinat, dan statin. Hiperlipidemia merupakan kelompok penyakit yang dapat bersifat primer atau sekunder, tergantung penyebabnya. Namun, dengan pemberian obat hipolipidemik mempunyai efikasi yang terbatas dan efek samping yang tidak diinginkan [1]. Hal inilah yang menjadi penyebab meningkatnya ketertarikan penggunaan bahan tradisional dari tumbuhan untuk menangani hiperlipidemia.

Buah-buahan dan sayuran banyak mengandung mikronutrien berupa polifenol (fenolik). Terdapat bukti efek menguntungkan dari polifenol terhadap risiko penyakit degeneratif seperti penyakit kardiovaskular [2]. Hasil skrining fitokimia buah oyong ditemukan kandungan senyawa flavonoid dan tanin golongan polifenol yang ditarik dari pelarut metanol [3].

Hal inilah yang mendasari dilakukannya penelitian untuk mengetahui ekstrak etanol buah oyong terhadap efek penurunan kadar kolesterol pada tikus putih yang dibuat tinggi kolesrerol dengan pemberian pakan tinggi lemak dan PTU.

\section{METODOLOGI PENELITAN}

\section{Bahan}

Bahan yang akan diteliti adalah buah oyong, buah muda yang masih segar berwarna hijau dengan panjang $15-20 \mathrm{~cm}$ dan diameter 5-7 cm. Determinasi sampel uji dilakukan pada Laboratorium Fakultas Kehutanan Universitas Mulawarman, Samarinda. Bahan kimia yang digunakan dalam penelitian ini adalah kit reagen kolesterol total, obat simvastatin $10 \mathrm{mg}$, aquadest, etanol $90 \%$, PTU (propiltiourasil) $100 \mathrm{mg}$ dan $\mathrm{Na}-\mathrm{CMC} \mathrm{0,5 \% .}$

\begin{abstract}
Alat
Alat yang digunakan dalam penelitian adalah alat-alat gelas, cawan porselein, Semi-automatic Chemistry Analyzer (FAST F-7000D), Rotary
\end{abstract}


Evaporator, timbangan analitik, Soxhlet, Water Bath, blender, oven, spoid $1 \mathrm{~mL}$ dan sonde, kandang pemeliharaan hewan.

\section{Pembuatan Pakan Tinggi Lemak}

Pakan tinggi lemak memiliki komposisi $0,5 \mathrm{~g}$ pelet lele, $1,5 \mathrm{Kg}$ pur ayam, 1 liter air, $1 \mathrm{Kg}$ tepung terigu, $2 \mathrm{Kg}$ lemak kambing, 10 butir kuning telur bebek dan $1 \mathrm{Kg}$ mentega [4]. Dan disimpan dalam lemari dengan suhu $\pm 40^{\circ} \mathrm{C}$.

\section{Persiapan Sampel}

Buah oyong diperoleh dari Desa Bukit Pariyaman, Kabupaten Kutai Kertanegara, Kecamatan Tenggarong Seberang, Kalimantan Timur. Sampel buah segar dicuci bersih dengan air mengalir dan dipotong tampak melintang, kemudian dikeringkan dalam oven suhu $40^{\circ} \mathrm{C}$. Setelah diperoleh simplisia kering, kemudian disoxhlet mengunakan etanol 90\% sebanyak $700 \mathrm{~mL}$ untuk tiap $250 \mathrm{~g}$ bungkusan simplisia kering hingga warna larutan bening. Sampel disaring sehingga didapatkan ekstrak etanol buah oyong, dipekatkan dengan menggunakan rotary evaporator pada suhu $30-40{ }^{\circ} \mathrm{C}$ sehingga didapatkan ekstrak kental buah oyong. Setelah itu diuapkan sisa pelarutnya dengan cara diangin-anginkan untuk mendapatkan ekstrak kering. Ekstrak kemudian disimpan dalam wadah tertutup rapat dan terhindar dari cahaya.

\section{Penanganan Hewan Uji}

Hewan yang digunakan ialah tikus putih berumur 2-3 bulan. Hewan coba diaklimitasi (adaptasi) selama 14 hari dalam kandang hewan dengan pemberian pakan standar dan air minum.

Kemudian dikelompokan menjadi 5 kelompok dengan 3 ekor utuk masingmasing kelompoknya. Kelompok 1 sebagai kontrol positif yang diberikan suspensi obat simvastatin. Kelompok 2 sebagai kontrol negatif yang berikan Na-CMC 0,5\%. Kelompok 3, 4, dan 5 diberikan ekstrak kental peroral dengan dosis 30mg / $200 \mathrm{~g}$ $\mathrm{BB}, 50 \mathrm{mg} / 200 \mathrm{~g}$ BB dan $70 \mathrm{mg} / 200 \mathrm{~g} \mathrm{BB}$ per hari. Diberikan pakan tinggi lemak selama 2 minggu dan terapi selama 2 minggu.

\section{Pengukuran Kadar Kolesterol Total}

Hewan uji digunting bagian ekor (vena latralis) dan dikumpulkan dalam microtube, kemudian disentrifugasi $5000 \mathrm{rpm}$ selama 15 menit dan diperoleh serum. Diukur dengan alat Semi-Automatic Chemical Analyzer. Pengukuran dilakukan pada awal, pertengahan, dan akhir perlakuan.

\section{HASIL DAN PEMBAHASAN}

Pengukuran kadar kolesterol total dalam tubuh menjadi suatu hal yang penting, untuk mengetahui dan menjaga kondisi normal kolesterol dalam tubuh yang memiliki peran dalam pembetukan hormon, cadangan energi dan pembentukan membran sel. Diperkirakan kondisi dengan kadar kolesterol melebihi 
rentang normal dapat meningkatkan faktor penyakit arteroskeloris bahkan penyakit jantung koroner. Penelitian dilakukan untuk mengetahui apakah ekstrak etanol 90\% buah oyong dapat menurunkan kadar kolesterol total yang dibandingkan dengan obat simvastatin.

Seluruh kelompok diadaptasi selama 2 minggu dengan pemberian pakan standar dan minum yang cukup. Tujuannya agar hewan uji terbiasa dengan kondisi kandang dan agar dapat mengamati hewan uji yang layak untuk diberi perlakuan uji, yaitu tikus yang aktif, bulu putih bersih dan memiliki berat badan 180-200 gram.

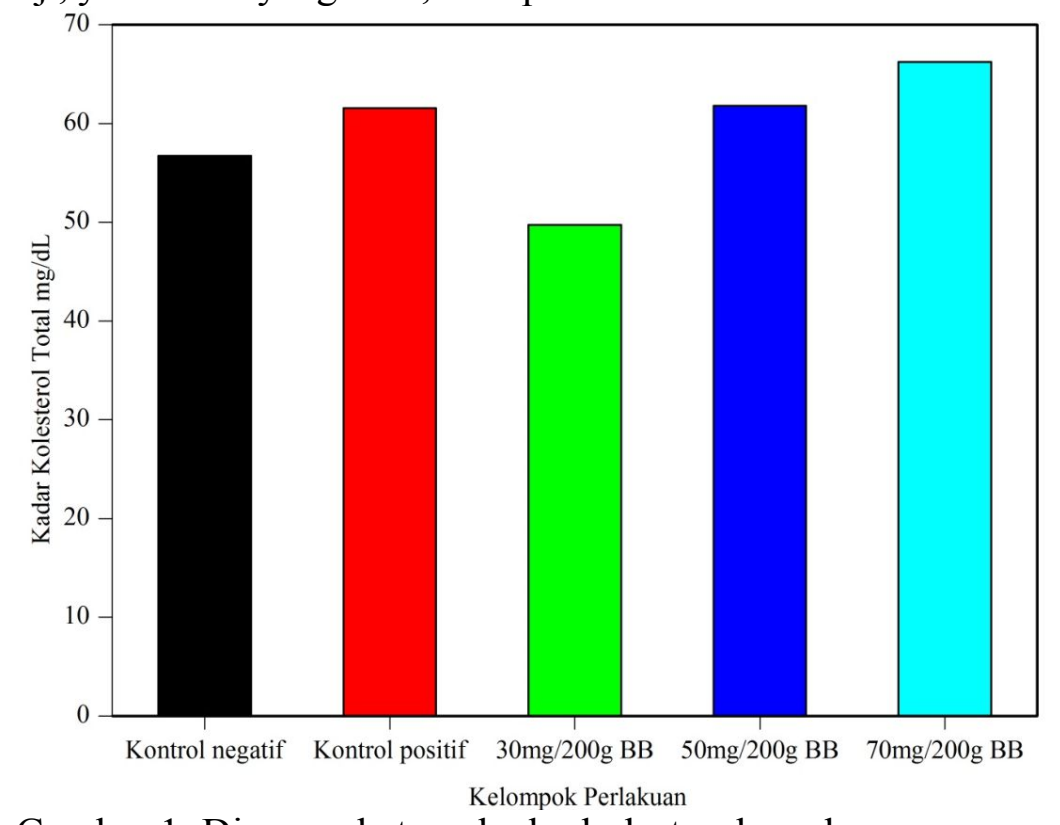

Gambar 1. Diagram batang kadar kolesterol awal

Pengukuran awal ini dilakukan untuk menunjukkan rentang normal kadar kolesterol tiap kelompok. Kelompok dosis $70 \mathrm{mg} / 200 \mathrm{~g}$ BB memiliki kadar kolesterol total yang lebih tinggi. Namun, dalam statistika dengan uji ANOVA $p \geq 0,05$ tidak menunjukan perbedaan bermakna kadar kolesterol awal dari seluruh kelompok. 


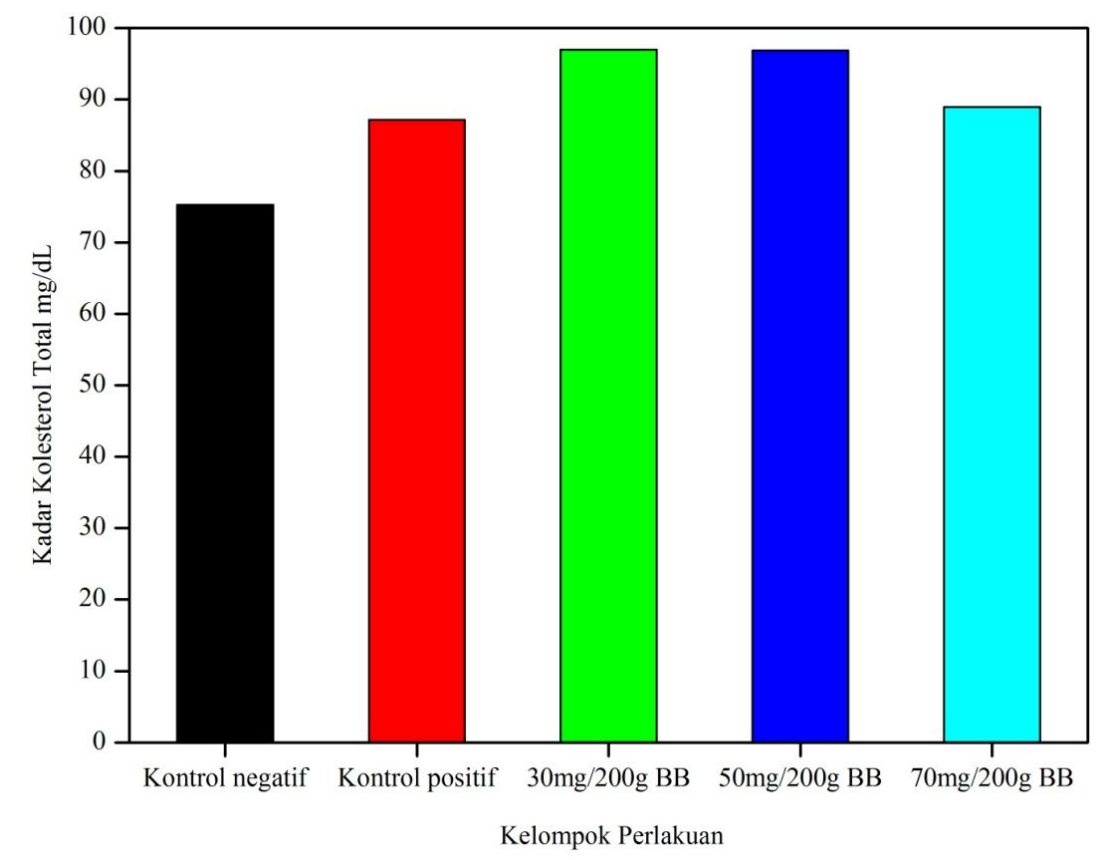

Gambar 2. Diagram batang kadar kolesterol induksi

Kemudian tikus diinduksi dengan pakan tinggi lemak dan suspensi PTU 0,01\% selama 2 minggu untuk meningkatkan kadar kolesterol total diseluruh kelompok perlakuan. Seluruh hewan uji dikelompokan dengan Randomized method untuk menghilangkan intervensi penelti dan hewan uji diberi sekat untuk mengatur jumlah makanan yang diberikan $20 \mathrm{~g}$ perhari. Propiltiourasil (PTU) sebagai sebagai obat hipotiroid meningkatkan kadar kolesterol total dengan menghambat pembentukan hormon tiroid yang ikut ambil peran meningkatkan ambilan kolesterol oleh reseptor LDL di hati serta meningkatkan aktivitas HDL. Sehingga apabila hormon tiroid dihambat, maka sintesis kolesterol oleh hati tidak maksimal meyebabkan kadar kolesterol meningkat dalam darah. Pakan ternak yang diberikan dapat menaikkan kadar kolseterol total karena banyak mengandung asam lemak jenuh dan trigliserida sebagai suplai pembentukan molekul kolesterol dalam tubuh.

Keaadan hiperlipid pada hewan uji dibuktikan dengan peningkatakan berat badan pada seluruh kelompok uji dan kadar signifikansi peningkatan kadar kolesterol total dalam darah tikus. 


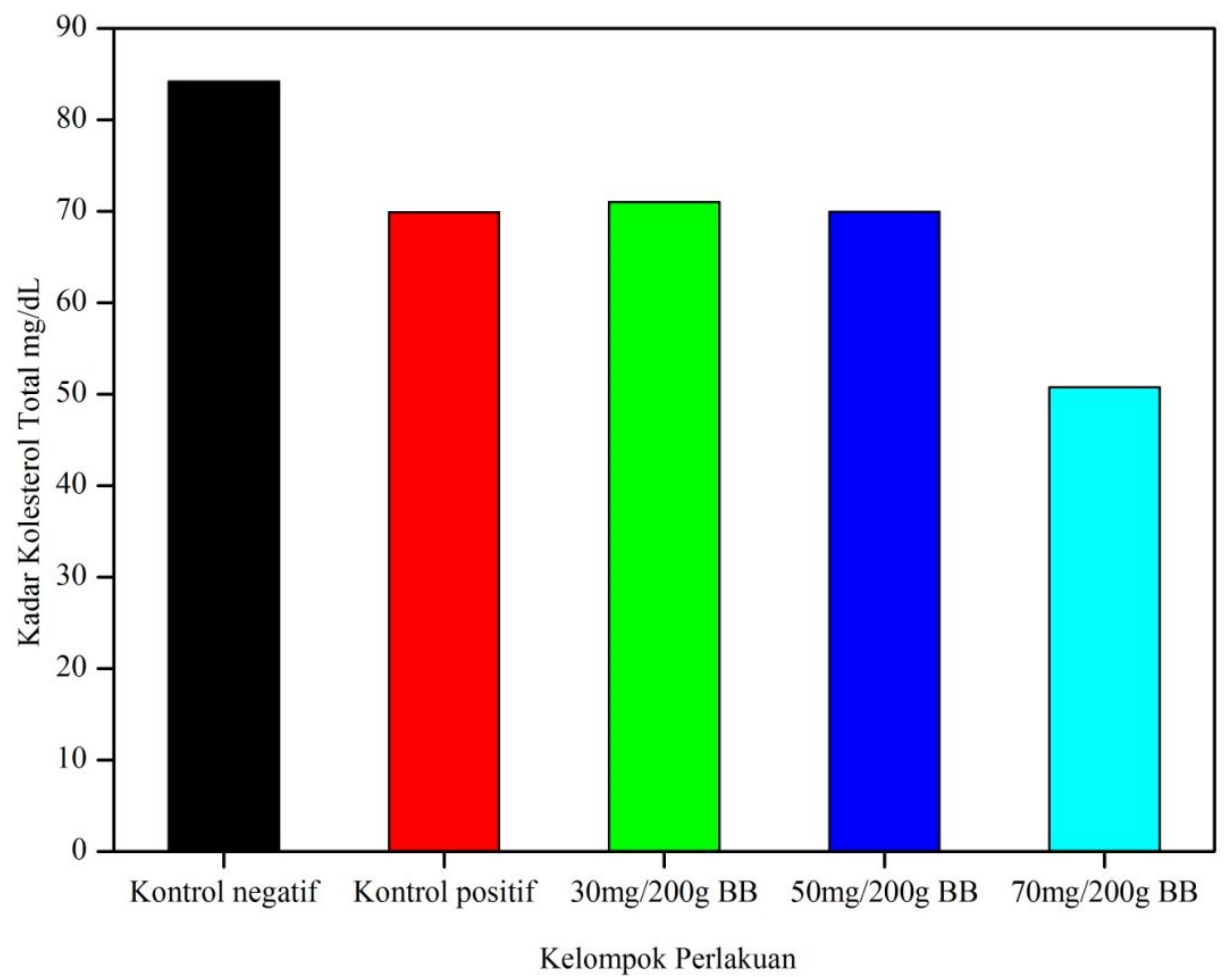

Gambar 3. Diagram batang kadar kolesterol terapi

Penelitian efek penurunan kadar kolesterol pada tikus putih setelah 2 minggu diberi pakan tinggi lemak dan diterapi (pemberian bahan uji) selama 2 minggu serta penghentian pemeberian pakan tinggi lemak. Kelompok kontrol negatif tidak megalami penurunan kadar kolesterol bahkan kadar kolesterol mengalami kenaikan karena kelompok ini tidak diberikan obat atau bahan hipolipid. Kelompok kontrol positif dengan suspensi simvastatin dengan mekanisme kerja obat menghambat reduktase 3-hidroksi-3-metil-glutaryl (HMG)-CoA pada tahap awal pembentukan sterol, mengalami penurunan menjadi 69,9233 $\pm 11,90762$. Sedangkan, kelompok dosis 30mg/200 g BB menjadi 71,0400 $\pm 26,75697$, kelompok dosis $50 \mathrm{mg} / 200 \mathrm{~g}$ BB penurunan menjadi $69,9733 \pm 20,09827$ dan kelompok dosis $70 \mathrm{mg} / 200 \mathrm{~g}$ BB penurunan menjadi $50,7700 \pm 5,41100$.

Namun, pada seluruh kelompok tidak terjadi penurunan berat badan, walaupun pakan tinggi lemaknya telah digantikan dengan pakan standar. Hal ini dikarenakan pakan standar yang diberikan mengandung karbohidrat yang dapat meningkatkan berat badan tikus. 


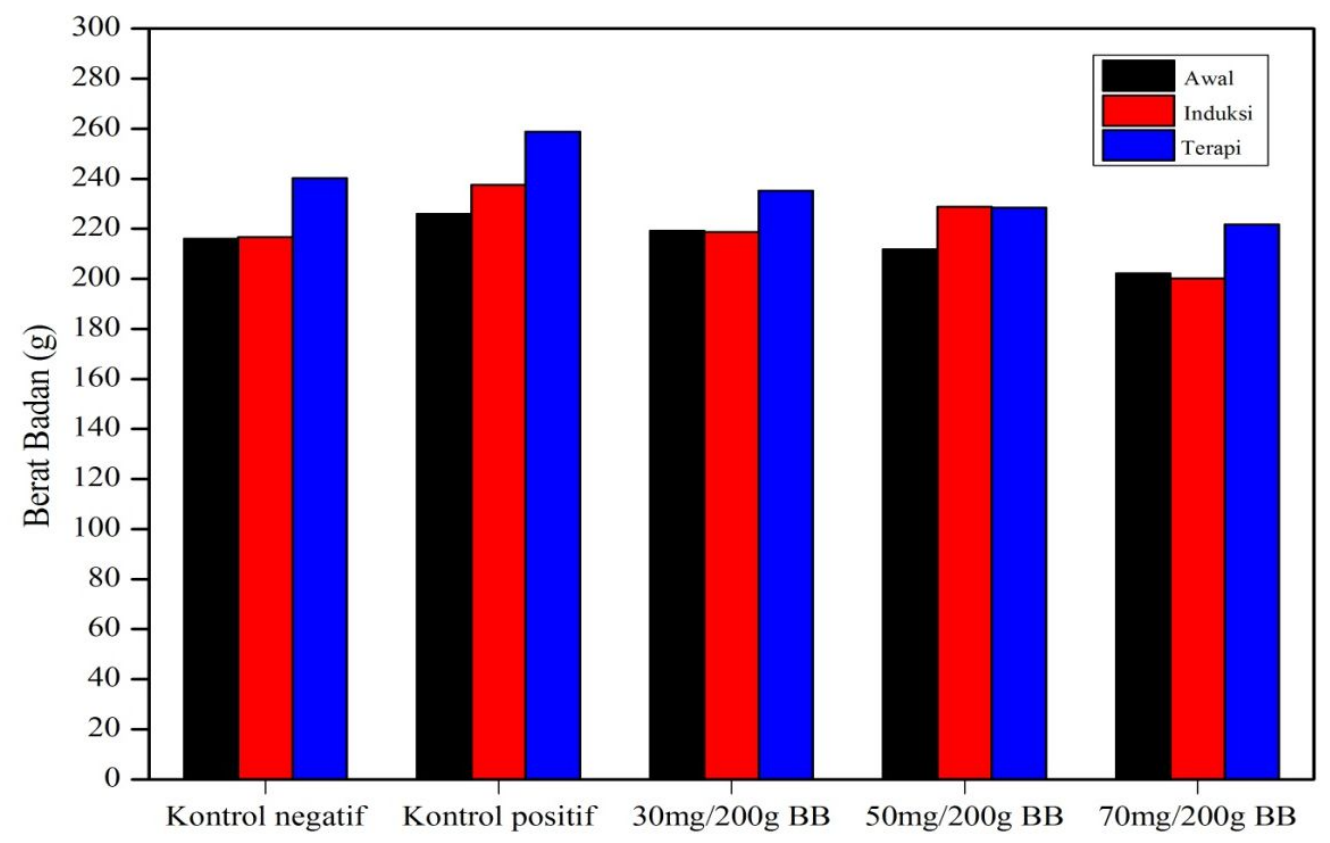

Gambar 4. Diagram batang berat badan tikus

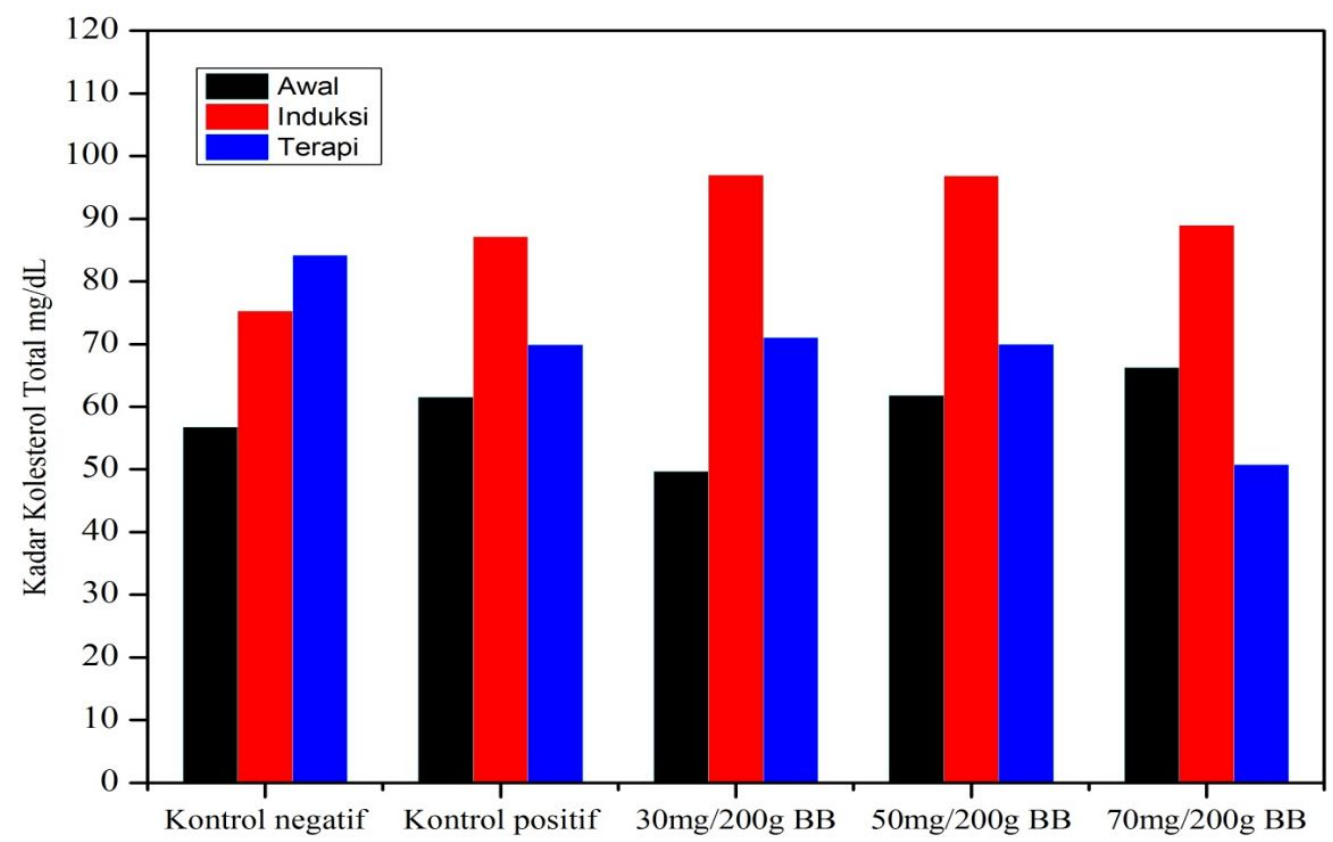

Gambar 4. Diagram batang kadar kolesterol

Data hasil kadar kolesterol total kelompok uji mengalami penurunan jika dibandingkan dengan kelompok kontrol negatif. Berdasarkan uji statistika ANOVA terdapat perbedaaan yang signifikan kelompok uji $30 \mathrm{mg} / 200 \mathrm{~g}$ BB $(p=0,008)$, $50 \mathrm{mg} / 200 \mathrm{~g}$ BB $(p=0,006)$ dan $70 \mathrm{mg} / 200 \mathrm{~g}$ BB $(p=0,001)$. Namun, tidak ada 
perbedaan penurunan kadar kolesterol total antara kelompok uji dengan kontrol positif

Kandungan metabolit sekunder dalam buah oyong yang diduga sebagai penurun kadar kolesterol total ialah flavonoid. Flavonoid menurunkan sintesis kolesterol dengan menghambat reduktase 3-hidroksi-3-metil-glutaryl (HMG)-CoA dan menghambat sekresi triasilgliserol [5]. Flavonoid juga memiliki banyak peran di dalam tubuh. Sebagai antioksidan, flavonoid bertindak sebagai pereduksi LDL di dalam tubuh [6].

\section{KESIMPULAN}

Kelompok dosis 30mg/200 g BB, 50mg/200 g BB, dan 70mg/200 g BB menunjukan penurunan kadar kolesterol total pada tikus yang diinduksi pakan tinggi lemak jika dibandingkan dengan kontrol negatif. Semakin besar dosis ekstrak yang diberikan, maka penurunan kadar kolesterol semakin besar.

\section{DAFTAR PUSTAKA}

[1] Kreisberg, Robert A, Albert Oberman. 2003. Medical Management of Hyperlipidemia or Dyslipidemia. The Journal of Clinical Endocrinology and Metabolism. 88 (6). 2445-2461.

[2] Manach, C., Scalbert, A., Morand, C., Rémésy, C. and Jiménez, L. 2004. Polyphenols, Food Sources and Bioavailability. American Journal of Clinical Nutrition. 79 (5). 727-747.

[3] Pimple, B.P., Kadam, P.V., dan Patil, M.J. 2011. Antidiabetic and Antihyperlipidemia Activity of Luffa Acutangula Fruit Extract in Streptozotosin Induced NIDDM rats. Asian Journal of Pharmaceutical and Clinical Research. 4 (2). 156-163.

[4] Direktorat Gizi Departemen Kesehatan RI. 1891. Daftar Komposisi Bahan Makanan: Jakarta.

[5] Casaschi, A., Maiyoh, G. K., Rubio, B. K., Li, R. W., Adeli, K. and Theriault, A. G. 2004. The Chalcone Xanthohumol Inhibits Triglyceride and Apolipoprotein B Secretion In HepG2 Cells. Journal of Nutrition. 134 (6). 1340-1346.Radhika, S., K.H. Smila and R. Muthezhilan. 2011. Antidiabetic and Hypolipidemic Activity of Punica granatum Linn on Alloxan Induced Rats. World Journal of Medical Sciences 6 (4): 178-182. 